\title{
Contribution of Latex Micro Diagnosis to Modern Management of Rubber Plantations: Case of Clones With Low or Slow Metabolism PB 217 and PR 107
}

\author{
Adou Bini Yao Christophe \\ Université Nangui Abrogoua, UFR Sciences de la Nature, \\ Laboratoire de Biologie et Amélioration des Productions Végétales, \\ Abidjan, Côte d'Ivoire \\ Okoma Koffi Mathurin \\ Centre National de Recherche Agronomique (CNRA), \\ Laboratoire Central de Biotechnologie, Abidjan, Côte d'Ivoire \\ Obouayeba Abba Pacôme \\ Université Jean Lorougnon, UFR Agroforesterie, \\ Laboratoire de Biochimie, Daloa, Côte d'Ivoire \\ Atsin Guy Jö̈l Olivier \\ Centre National de Recherche Agronomique (CNRA), \\ Station de Recherche de Bimbresso, Abidjan, Côte d'Ivoire \\ Ballo Espérence Kouadio \\ Université Jean Lorougnon, UFR Agroforesterie, \\ Laboratoire de Physiologie et Pathologie Végétale, Daloa, Côte d'Ivoire \\ Essehi Jean-Lopez \\ Université Félix Houphouët-Boigny, UFR des Sciences de la Terre et des \\ ressources Minières, Laboratoire de Pédologie, Abidjan, Côte d'Ivoire

\section{Wahounou Polié Jean}

Centre National de Recherche Agronomique (CNRA),

Station de Recherche de Bimbresso, Abidjan, Côte d'Ivoire

Soumahin Eric Francis

Université Jean Lorougnon, UFR Agroforesterie,

Laboratoire de Physiologie et Pathologie Végétale, Daloa, Côte d'Ivoire

\section{Kouakou Tanoh Hilaire}

Université Nangui Abrogoua, UFR Sciences de la Nature, Laboratoire de Biologie et Amélioration des Productions Végétales, Abidjan,

Côte d'Ivoire

\section{Obouayeba Samuel}

Centre National de Recherche Agronomique (CNRA),

Station de Recherche de Bimbresso, Abidjan, Côte d'Ivoire 


\begin{abstract}
The cultivated rubber clones are sensitive to latex harvesting regimes according to their laticiferous metabolism. Thus, in order to determine the best latex harvesting systems of clones with low or slow metabolism, six latex harvesting technologies are applied to them in a bulk statistical device from Fisher to four rehearsals. The rubber is tapped in downward half spiral stimulated or not for nine years after the opening of the tapping panel. The agronomic parameters (production, vegetative growth), the tapping panel dryness and those of the latex micro diagnosis were evaluated. The results indicate that these clones independently of the latex harvesting system have good rubber productivity $\left(2310 \mathrm{~kg} \cdot \mathrm{ha}^{-1} \cdot \mathrm{y}^{-1}\right)$ with good radial vegetative growth $\left(2.9 \mathrm{~cm}^{-1} \mathrm{y}^{-1}\right)$. Their trees show a well-balanced physiological profile and an acceptable sensitivity to the tapping panel dryness (4.9\%). However, the physiological index, the bark consumption and the sensitivity to the tapping panel dryness lead to retain the latex harvesting technologies "S/2 d3 6d/7 Pa1(1) ET2.5\% 4/y, S/2 d4 6d/7 Pa1(1) ET2.5\% 4/y and S/2 d4 6d/7 Pa1(1) ET2.5\% 8/y" for the best. This index, favorably influencing the choice of technologies adapted to clones with active metabolism, contributes to the modern and efficient management of a rubber plantation.
\end{abstract}

Keywords: Hevea brasiliensis, latex harvesting technology, tapping panel dryness, rubber production, physiological parameters, Côte d'Ivoire

\title{
Introduction
}

The production of rubber from a rubber plantation inevitably results from tapping (Serres et al. 1994; Obouayeba et al. 2000). It is obtained from an incision (cut) of the tissues of the trunk bark (Obouayeba et al. 2000). As a result of this incision, the laticiferous vessels, which are specialized tissues, with special rubber-producing cells (laticiferous), are severed leaving the latex from which the natural rubber is extracted (Obouayeba et al. 2000). However, the tapping of trees in a plantation makes it possible to produce rubber, but this production is limited (Traoré et al. 2014). It cannot be adapted to the needs of the users and, above all, tapping alone cannot make it possible to improve the production potential of the different rubber clones (Jacob et al. 1988). These potentialities are indeed dependent on the metabolic function of the laticiferous cell of these clones. To address these concerns, nowadays and in a systematic way, the hormonal stimulation of rubber production (Obouayeba, 1995 and 2009; Soumahin, 2010) is added to the tapping system. This consists in applying to the tree a stimulating paste with an active ingredient concentration (Ethephon) ranging from 2.5 to $5 \%$ in order to improve its 
rubber productivity (Abraham et al. 1968). Latex harvesting systems improve the rubber productivity of plantations (Jacob et al. 1990). This productivity is also a function of the intensity of the applied latex harvesting system and the metabolic class of the cloned clone (Dian, 1997). The practice of tapping or a tapping system (Obouayeba, 1995 and 2009) and/or a strategy of hormonal stimulation of rubber production can constitute a system or technology for harvesting latex that is more or less intensive for a given clone. However, it is known that the most efficient latex harvesting technologies in rubber production weaken the physiological state of the trees. Thus, in order to sustain and even raise the productivity of rubber tree, many important studies have been carried out in the field of plant physiology and latex (Jacob et al. 1988). This work has made it possible to group clones currently cultivated into three classes of metabolic activity and to establish a clonal typology of the metabolic functioning of the laticiferous system (Eschbach et al. 1984, Jacob et al. 1988; Serres et al. 1994); Jacob et al. 1995; Gohet et al. 1996). The latter is based on the response to the hormonal stimulation of rubber production of the groups of clones concerned. Given the heavy investment in rubber production and the late return on investment, the management of a plantation must be modern through the use of the Latex Micro Diagnosis (LMD) in order to make the rubber production activities profitable over the long term. This requires the implementation of efficient latex harvesting technologies adapted to the clonal laticiferous metabolisms, that is to say they are durable without damage to the trees. For this purpose, the physiological profile of the rubber obtained from the four parameters of the Latex Micro Diagnosis (LMD) of slow metabolism clones (PB 217 and PR 107) subjected to six (6) of the latex harvesting technologies is analyzed to determine the best.

\section{Materials and Methods \\ Plant Material}

The plant material is composed by clones PB 217 and PR 107, described as follows:

- $\quad$ Clone PB 217 is native to Malaysia (Prang Besar), with female parent $\mathrm{PB} 5 / 51$ and male parent $\mathrm{PB}$ 6/9. Its vegetative growth before bleeding is comparable to that of GT 1 (Obouayeba et al. 2000; Obouayeba, 2005). It is a vigorous but very heterogeneous clone. It has a difficult flow. Its average production, the first three years, is constantly advancing; making this clone a top producer (Soumahin, 2010). According to the latter, the physiological characteristics of this clone result in slow metabolism, high carbohydrate stores as well as high levels of thiols;

- $\quad$ The first planting of PR 107 (Proefstationvoor 107) was established in Côte d'Ivoire in 1959. In the first five years of tapping, PR 107 is less vigorous and more productive than clone GT 1 but very productive after 6 to 10 years 
of tapping (Chapuset, 2001). It is appreciated for its resistance to breakage due to wind, its high productivity in rubber and its low sensitivity to the tapping panel dryness (Chapuset, 2001), then its good response to hormonal stimulation (Soumahin, 2010; Obouayeba et al. 2000; Gohet, 1996).

\section{Experimental Design}

The trees of those different clones were planted at the density of 510 trees per ha $(7 \mathrm{~m} \times 2.8 \mathrm{~m})$ since 1988 in straight lines. RCB (Randomized Complete Bloc) of 6 treatments and 4 repetitions were used as experimental design with around 100 trees per plot.

The test covers an average area of 4.7 ha. This trial was set up on the Gô research station in south-western Côte d'Ivoire.

The experiments were started in April 1996 at the opening of the trees at $1.20 \mathrm{~m}$ above the ground and were completed in March 2005 for the clone PB 217 and from April 1999 to April 2008 for the clone PB 260.

\section{Treatments}

The trees were opened at height of $1.20 \mathrm{~m}$ (panel BO-1). The tapping systems imposed and the intensity of tapping are shown below in Table 1:

\section{Tapping}

Two tappers were employed with repetitions. A and B assigned to tapper A, and repetitions C and D to tapper B Average consumption of bark (perpendicular to the tapping cut) were:

- $\quad \mathrm{d} 2: 1.0$ to $1.3 \mathrm{~mm} /$ tapping, 156 tapping per years (156 to $203 \mathrm{~mm} / \mathrm{y}$ )

- $\quad \mathrm{d} 3$ : 1.3 to $1.5 \mathrm{~mm} /$ tapping, 104 tapping per years (135 to $156 \mathrm{~mm} / \mathrm{y}$ )

- $\quad \mathrm{d} 4: 1.5$ to $1.8 \mathrm{~mm} /$ tapping, 78 tapping per years (117 to $140 \mathrm{~mm} / \mathrm{y}$ )

- $\quad \mathrm{d} 5: 1.7$ to $2.0 \mathrm{~mm} /$ tapping, 65 tapping per years (110 to $130 \mathrm{~mm} / \mathrm{y}$ )

- $\quad \mathrm{d} 6: 1.8$ to $2.0 \mathrm{~mm} /$ tapping, 52 tapping per years (93 to $104 \mathrm{~mm} / \mathrm{y}$ )

\section{Hormonal Stimulation}

All selected trees were stimulated on the tapping panel, on a $1 \mathrm{~cm}$ wideband, due to $1 \mathrm{~g}$ of stimulant per tree (Obouayeba, 1993; Traoré et al. 2014).The stimulating product used is obtained by mixing Ethrel and palm oil. Ethrel contains $2.5 \%$ of active ingredient which is 2-chloroethylphosphonic acid or Ethephon (CEPA).

\section{Production of Rubber}

Rubber production of each treatment was weighed every 4 weeks using a scale. Samples of fresh rubber were collected for each treatment to determine the coefficient of transformation (CT) which was used to calculate the 
production of dry rubber expressed in kilograms per hectare per year $\left(\mathrm{kg} . \mathrm{ha}^{-}\right.$ $\left.{ }^{1} \cdot \mathrm{y}^{-1}\right)$.

Table 1: Treatments applied in tapping downward to clones PB 217 and PR 107 during nine years of experimentation in southwestern Cote d'Ivoire

\begin{tabular}{|c|c|c|c|}
\hline $\mathrm{N}^{\circ}$ & Treatments & TI $(\%)$ & Description \\
\hline 1 & $\begin{array}{l}\mathrm{S} / 2 \mathrm{~d} 26 \mathrm{~d} / 7, \text { nil } \\
\text { stimulation }\end{array}$ & 100 & $\begin{array}{l}\text { Half spiral cut tapped at alternate daily } \\
\text { frequency, six day in tapping followed by one } \\
\text { day rest, not stimulated }\end{array}$ \\
\hline 2 & $\begin{array}{l}\mathrm{S} / 2 \mathrm{~d} 36 \mathrm{~d} / 7 \mathrm{ET} 2.5 \% \\
\mathrm{~Pa} 1(1) 4 / \mathrm{y}\end{array}$ & 67 & $\begin{array}{l}\text { Half spiral cut tapped at third daily frequency, } \\
\text { six day in tapping followed by one day; } \\
\text { stimulated with Ethephon of } 2.5 \% \text { active } \\
\text { ingredient with } 1 \mathrm{~g} \text { of stimulant applied on } \\
\text { panel on a } 1 \mathrm{~cm} \text { band, } 4 \text { applications per year. }\end{array}$ \\
\hline 3 & $\begin{array}{l}\mathrm{S} / 2 \mathrm{~d} 4 \text { 6d/7 ET2.5\% } \\
\mathrm{Pa}(1) 4 / \mathrm{y}\end{array}$ & 50 & $\begin{array}{l}\text { Half spiral cut tapped at fourth daily frequency, } \\
\text { six day in tapping followed by one day; } \\
\text { stimulated with Ethephon of } 2.5 \% \text { active } \\
\text { ingredient with } 1 \mathrm{~g} \text { of stimulant applied on } \\
\text { panel on a } 1 \mathrm{~cm} \text { band, } 4 \text { applications per year. }\end{array}$ \\
\hline 4 & $\begin{array}{l}\mathrm{S} / 2 \mathrm{~d} 4 \text { 6d/7 ET2.5\% } \\
\mathrm{Pa}(1) \text { 8/y }\end{array}$ & 50 & $\begin{array}{l}\text { Half spiral cut tapped at fourth daily frequency, } \\
\text { six day in tapping followed by one day; } \\
\text { stimulated with Ethephon of } 2.5 \% \text { active } \\
\text { ingredient with } 1 \mathrm{~g} \text { of stimulant applied on } \\
\text { panel on a } 1 \mathrm{~cm} \text { band, } 8 \text { applications per year. }\end{array}$ \\
\hline 5 & $\begin{array}{l}\mathrm{S} / 2 \mathrm{~d} 5 \text { 6d/7 ET2.5\% } \\
\mathrm{Pa}(1) \text { 8/y }\end{array}$ & 40 & $\begin{array}{l}\text { Half spiral cut tapped at fifth daily frequency, } \\
\text { six day in tapping followed by one day; } \\
\text { stimulated with Ethephon of } 2.5 \% \text { active } \\
\text { ingredient with } 1 \mathrm{~g} \text { of stimulant applied on } \\
\text { panel on a } 1 \mathrm{~cm} \text { band, } 8 \text { applications per year. }\end{array}$ \\
\hline 6 & $\begin{array}{l}\mathrm{S} / 2 \mathrm{~d} 6 \text { 6d/7 ET2.5\% } \\
\mathrm{Pa}(1) 10 / \mathrm{y}\end{array}$ & 33 & $\begin{array}{l}\text { Half spiral cut tapped at sixth daily frequency, } \\
\text { six day in tapping followed by one day; } \\
\text { stimulated with Ethephon of } 2.5 \% \text { active } \\
\text { ingredient with } 1 \mathrm{~g} \text { of stimulant applied on } \\
\text { panel on a } 1 \mathrm{~cm} \text { band, } 10 \text { applications per year. }\end{array}$ \\
\hline
\end{tabular}

TI: Tapping Intensity

\section{Radial Vegetative Growth}

The circumferences of trees were measured annually in April (opening trees in April 1996 for clone PB 217 and in April 1997 the clone PR 107). The measurements were made at the height of $1.70 \mathrm{~m}$ above the ground using a measuring tape.

\section{Rates of Tapping Panel Dryness}

The percentage of tapping panel dryness was determined visually. This rate was obtained by taking into account of percentage of dry trees. 


\section{Latex Micro Diagnosis}

From the latex sampled, it was possible to determine annually, by the Latex Micro Diagnosis (LMD) method, the levels of dry rubber content (solids content: ExS) and the contents of sucrose (Sac), inorganic phosphorus (Pi) and thiol groups (thiol compounds: R-SH) of the latex. The solids content was determined according to the method described by Eschbach et al. (1984), while the contents of sucrose, inorganic phosphorus and thiol compounds were obtained respectively by Ashwel (1957), Taussky and Shorr (1953) and Boyne and Ellman (1972). The LMD data were analyzed on the basis of the reference values established by Jacob et al. (1987) and interpreted according to the Roussel interpretation scheme (Jacob et al. 1987).

\section{Physiological Index}

Physiological studies have shown the strong involvement of certain physiological parameters in the production of rubber (Jacob et al. 1985) and, consequently, allowed the prediction of rubber production (Koffi et al. 2004). The influence of these physiological parameters on the production of rubber may or may not vary from one technology of harvesting the latex to another. Thus, we define the physiological index as the product of the average concentrations of Sucrose (Sac), Inorganic Phosphorus (Pi) and Thiol compounds (R-SH) at a given time. We believe, with this physiological index, to better discriminate the latex harvesting systems applied to rubber trees.

\section{Determination of Better Latex Harvesting Systems}

In order to determine the best latex harvesting systems, the physiological parameters taken into account in the realization of the latex micro diagnosis (dry rubber content, sucrose, inorganic phosphorus and thiol compounds) and those of production, isodiametric growth and tapping panel dryness sensitivity have been put to use. The mean values of these parameters were subjected to an analysis of variance. This made it possible to classify the different latex harvesting technologies according to their effect on the parameters studied. The best technologies for latex harvesting have been those that have produced both:

$>\quad$ A high level of rubber production;

$>\quad$ Low impact on isodiametric growth;

$>\quad$ Low sensitivity to the tapping panel dryness, expressed by low percentages of LEM;

$>\quad$ A good physiological profile with dry rubber content, sucrose, inorganic phosphorus and thiol compounds ranging from medium to high.

\section{Statistical Analysis}

An analysis of variance of the data including the rubber yield, vegetative radial growth, latex micro diagnostic and tapping panel dryness was 
done with the SAS statistical software and the Student-Newman-Keuls test, at $\mathrm{P}<0.05$.

\section{Results and Discussion}

Influence of Latex Harvesting Technologies on Agronomic Parameters Clones PB 217 and PR 107

Clone $P B$ 217. Average annual production of rubber per hectare (downward tapping), with all latex harvesting technologies, reached $1988 \mathrm{~kg}$ (Table 2). This production has not changed with respect to latex harvesting technologies applied to trees. The increase in stimulation frequency did not have a significant effect on production when tapping was performed every 4 days (treatments 3 and 4). Similarly, the passage of tapping frequencies every 4 days to every 5 days (treatments 4 and 5 ) for the same stimulation frequency $(8 / y)$ did not have a significant impact on production.

Clone PR 107.Rubber yields varied from 1994 to $2283 \mathrm{~kg} \cdot \mathrm{ha}^{-1} \cdot \mathrm{y}^{-1}$, with an average of $2065 \mathrm{~kg} \cdot \mathrm{ha}^{-1} \cdot \mathrm{y}^{-1}$ (Table 2). The trees in treatment $2(\mathrm{~d} 3-4 / \mathrm{y})$ were significantly higher. Under hormonal stimulation, the yield of rubber decreased with the reduction in the frequency of tapping. Conversely, for the same stimulation frequency, the yield increased with the intensity of the tapping frequency. The d2-nil stim system, with $100 \%$ tapping intensity, recorded the lowest yield of rubber $\left(1833 \mathrm{~kg} \cdot \mathrm{ha}^{-1} \cdot \mathrm{y}^{-1}\right)$.

The average annual yield of dry rubber, all latex harvest technologies and all clones combined, reached $2026 \mathrm{~kg} \cdot \mathrm{ha}^{-1} \cdot \mathrm{y}^{-1}$. This yield did not distinguish latex harvesting technologies (Table 2). The mean dry rubber yield of clone PB 217 (1988 $\left.\mathrm{kg} \cdot \mathrm{ha}^{-1} \cdot \mathrm{y}^{-1}\right)$ was statistically of the same order of magnitude as that of clone PR 107 (2065 kg.ha- $\left.{ }^{-1} \cdot \mathrm{y}^{-1}\right)$.

Table 2: Average annual dry rubber production expressed in $\mathrm{kg} \cdot \mathrm{ha}^{-1} \cdot \mathrm{y}^{-1}$ in tapping downward of clones PB 217 and PR 107 for nine years in the south-west of Côte d'Ivoire

\begin{tabular}{llll}
\hline \multirow{2}{*}{ Treatments } & \multicolumn{2}{l}{ Dry rubber production $\left({\left.\mathrm{kg} \cdot \mathrm{ha}^{-1} \cdot \mathrm{y}^{-1}\right)}\right.$} \\
\cline { 2 - 3 } & PB 217 & PR 107 & Mean \\
\hline $\mathrm{S} / 2 \mathrm{~d} 2$ 6d/7 nil stimulation & $1860 \mathrm{a}$ & $1833 \mathrm{~d}$ & $1849 \mathrm{~A}$ \\
$\mathrm{~S} / 2 \mathrm{~d} 36 \mathrm{~d} / 7 \mathrm{ET} 2.5 \%$ Pa1(1) 4/y & $2131 \mathrm{a}$ & $2283 \mathrm{a}$ & $2256 \mathrm{~A}$ \\
$\mathrm{~S} / 2 \mathrm{~d} 4$ 6d/7 ET2.5\% Pa1(1) 4/y & $1993 \mathrm{a}$ & $2036 \mathrm{bc}$ & $2015 \mathrm{~A}$ \\
$\mathrm{~S} / 2 \mathrm{~d} 4$ 6d/7 ET2.5\% Pa1(1) 8/y & $2142 \mathrm{a}$ & $2192 \mathrm{~b}$ & $2166 \mathrm{~A}$ \\
$\mathrm{~S} / 2 \mathrm{~d} 5$ 6d/7 ET2.5\% Pa1(1) 8/y & $1986 \mathrm{a}$ & $2051 \mathrm{bc}$ & $2018 \mathrm{~A}$ \\
$\mathrm{~S} / 2 \mathrm{~d} 6$ 6d/7 ET2.5\% Pa1(1) 10/y & $1813 \mathrm{a}$ & $1994 \mathrm{c}$ & $1856 \mathrm{~A}$ \\
\hline Mean & $1988 \mathrm{~A}$ & $2065 \mathrm{~A}$ & 2026 \\
\hline
\end{tabular}

In each column, the values assigned to the same letter are not significantly different (Student Newman-Keuls test at $5 \%$ ). 
Rubber productions expressed in $\mathrm{kg} \cdot \mathrm{ha}^{-1} \cdot \mathrm{y}^{-1}$ are statistically identical regardless of the latex harvesting technology. This result seems to express a compensatory effect of the reduction of the tapping by the increase of the hormonal stimulation. This is because tapping produces an activating effect of the metabolism of rubber production as noted by Obouayeba et al. 1996 and Atsin et al. 2016. Indeed, tapping, by the stress it induces, activates the metabolism as well as hormonal stimulation by ethylene production (Chrestin, 1985 and Atsin et al. 2016).

Overall, the results show that, regardless of the treatment, production is good and clearly above the Ivorian national average $\left(\geq 1800 \mathrm{~kg} \cdot \mathrm{ha}^{-1} \cdot \mathrm{y}^{-1}\right)$ which is one of the best in the world. These productions can even reach 2283 $\mathrm{kg} \cdot \mathrm{ha}^{-1} \cdot \mathrm{y}^{-1}$. Our results on rubber yield show that agronomically all latex harvesting technologies applied to clones PB 217 and PR 107 in the context of our work have a statistically significant economic interest.

\section{Influence of Latex Harvesting Technologies on the Radial Vegetative Growth of Clones with slow metabolism PB 217 and PR 107}

All the latex harvesting technologies combined, the average annual increase in girth of the trees of clone PB $217\left(3.4 \mathrm{~cm} \cdot \mathrm{y}^{-1}\right)$ was significantly greater than that of the trees of clone PR $107\left(1.94 \mathrm{~cm}^{-1} \mathrm{y}^{-1}\right)$. These increases, regardless of the clone, did not statistically differentiate latex harvesting technologies, although the d2-nil stim and d6-10/y treatments recorded the highest values (Table 3). All technologies of latex harvesting and all clones combined, the average annual increase in tree circumference reached $2.6 \mathrm{~cm}$.

Table 3: Mean values of tree trunk circumference (cm. $\left.\mathrm{y}^{-1}\right)$ in clones PB 217 and PR 107 in tapping from treatment for nine years in the southwest Côte d'Ivoire

\begin{tabular}{llll}
\hline \multirow{2}{*}{ Treatments } & \multicolumn{3}{l}{ Tree trunk circumference growth $\left(\mathrm{cm}^{-1} \mathrm{y}^{-1}\right.$} \\
\cline { 2 - 4 } & PB 217 & PR 107 & Mean \\
\hline $\mathrm{S} / 2 \mathrm{~d} 2$ 6d/7 nil stimulation & $3,5 \mathrm{a}$ & $2,0 \mathrm{a}$ & $2,8 \mathrm{~A}$ \\
$\mathrm{~S} / 2 \mathrm{~d} 36 \mathrm{~d} / 7 \mathrm{ET} 2.5 \% \mathrm{~Pa} 1(1) 4 / \mathrm{y}$ & $3,1 \mathrm{a}$ & $1,7 \mathrm{a}$ & $2,4 \mathrm{~A}$ \\
$\mathrm{~S} / 2 \mathrm{~d} 4$ 6d/7 ET2.5\% Pa1(1) 4/y & $3,3 \mathrm{a}$ & $1,8 \mathrm{a}$ & $2,6 \mathrm{~A}$ \\
$\mathrm{~S} / 2 \mathrm{~d} 4$ 6d/7 ET2.5\% Pa1(1) 8/y & $3,4 \mathrm{a}$ & $1,7 \mathrm{a}$ & $2,6 \mathrm{~A}$ \\
$\mathrm{~S} / 2 \mathrm{~d} 5$ 6d/7 ET2.5\% Pa1(1) 8/y & $3,2 \mathrm{a}$ & $1,9 \mathrm{a}$ & $2,6 \mathrm{~A}$ \\
$\mathrm{~S} / 2 \mathrm{~d} 6$ 6d/7 ET2.5\% Pa1(1) 10/y & $3,5 \mathrm{a}$ & $2,0 \mathrm{a}$ & $2,8 \mathrm{~A}$ \\
\hline Mean & $3,4 \pm 0,2 \mathrm{~A}$ & $1,9 \pm 0,1 \mathrm{~B}$ & $2,6 \pm 0,1$ \\
\hline
\end{tabular}

In each column, the values assigned to the same letter are not significantly different (Student Newman-Keuls test at 5\%

The average annual tree circumference increase, all latex harvesting technologies and all clones combined is $2.6 \mathrm{~cm}$. This average annual increase 
in circumference is good and consistent with that of clones with moderate vegetative growth, such as the work of Obouayeba and Boa (1993) and Obouayeba et al. (2009) have indicated. This is particularly so since the yield of all clones and latex harvesting technologies combined reaches $2026 \mathrm{~kg}$.ha ${ }^{-}$ ${ }^{1} \cdot \mathrm{y}^{-1}$, as against $1903 \mathrm{~kg} \cdot \mathrm{ha}^{-1} \cdot \mathrm{y}^{-1}$ obtained from the clone IRCA 111 (Obouayeba et al. 2009). This level of increase is explained by the fact that the activation of the function of rubber production by hormonal stimulation causes an increase in the energy requirements, as well as assimilates (minerals, enzymes and organic elements) necessary for the synthesis of latex constituents, and therefore of rubber production (Gohet, 1996; Lacote et al. 2010). Given these increased needs, the rubber plant, the laticiferous cell, is obliged to use its reserves in the event of a shortage of assimilates (Jacob et al., 1988). The immediate consequence of this action is the reduction of vegetative growth (Obouayeba, 2005; Gohet, 1996). For this purpose, the clones possessing the strongest laticiferous wells, that is to say, exhibiting the highest intralaticiferous sucrose contents at a production level or an activation of the analogous metabolism, could be those for which the antagonism between growth and production is weakest and vice versa (Gohet, 1996). Isoprene biosynthesis would then have less influence on vegetative growth than the flow of available assimilates for this biosynthesis is important. Logically, it seems that a high production potential can limit the availability of laticiferous sugar and therefore the strength of the laticiferous well by competition for photosynthesis (Gohet, 1996). This last hypothesis is corroborated by our results of rubber production, of intralaticious sucrose content and above all of radial vegetative growth, less well, if not an opposition, to the fact that the more rubber the tree produces, the less develops as Diarrassouba et al. (2012); Obouayeba et al. (2002) and Obouayeba (2005) have pointed out. However, the depressive effect of hormonal stimulation on vegetative growth is attenuated by the reduction in tapping intensity, as the latter induces stress on the tree, which can play a stimulating role hormonal stimulation (Chrestin, 1985). This disagrees with our results where radial vegetative growth does not distinguish latex harvesting technologies. This similarity is due to the effect of the increase in the frequency of hormonal stimulation compensated by the reduction in the frequency of tapping. This is why the trees of the treatment S/2 d6 6d/7 ET2.5\% Pa1(1) 10/y have radically vegetative growth statistically equal to that of the unstimulated rubber trees.

\section{Influence of Latex Harvesting Technologies on the Tapping Panel Dryness Sensitivity of Clones PB 217 and PR 107}

Clone PB 217.The average rate of tapping panel dryness, with all latex harvesting technologies, reached a low level (4.0\%). However, it is median with treatment 1 (d2-nil stim), which had the highest tapping panel dryness 
rate $(5.8 \%)$. The latter is significantly higher than those of the other treatments which expressed statistically identical tapping panel dryness rates (Table 4).

Clone PR 107. The analysis of Table 5 indicates that the tapping panel dryness rates of the clone PR 107, all latex harvesting technologies, are extremely low (1\%). Although the overall rate was extremely low, treatment with no hormonal stimulation, with $100 \%$ tapping intensity, had the highest tapping panel dryness rate $(1.7 \%)$ and statistically different from the other treatments. The latter tapping panel dryness statistic is followed by that of treatment 4 (d4-8/y: $1.3 \%)$ which is slightly higher than that of treatments 2 $(\mathrm{d} 3-4 / 4)$ and $5(\mathrm{~d} 5-8 / \mathrm{y})$ with rates of the same order of magnitude $(1 \%)$. Treatments 3 (d4-4/y: 0.6\%) and 6 (d6-10/y: 0.4\%) showed the most statistically low tapping panel dryness rates.

All the latex harvesting technologies combined, the average annual tapping panel dryness rate of trees of clone PB 217 (4.0\%) was significantly higher than that of trees of clone PR 107 (1.0\%). Overall, the mean tapping panel dryness rate of trees of clones PB 217 and PR 107, with all latex harvesting technologies, reached $2.5 \%$ (Table 4). This low rate is significantly related to latex harvesting technology. Indeed, treatment with no hormonal stimulation, with $100 \%$ tapping intensity, had the highest tapping panel dryness rate $(3.8 \%)$ and statistically different from those of other treatments, the rates of which were statistically identical between them.

Table 4: Average tapping panel dryness rates of trees in clones PB 217 and PR 107, in tapping downward, according to treatments for nine years in south-west Côte d'Ivoire

\begin{tabular}{llll}
\hline \multirow{2}{*}{ Treatments } & \multicolumn{3}{l}{ Tapping panel dryness rates (\%) } \\
\cline { 2 - 4 } & PB 217 & PR 107 & Mean \\
\hline $\mathrm{S} / 2 \mathrm{~d} 2$ 6d/7 nil stimulation & $5,8 \mathrm{a}$ & $1,7 \mathrm{a}$ & $3,8 \mathrm{~A}$ \\
$\mathrm{~S} / 2 \mathrm{~d} 36 \mathrm{~d} / 7 \mathrm{ET} 2.5 \% \mathrm{~Pa} 1(1)$ 4/y & $3,1 \mathrm{~b}$ & $1,0 \mathrm{bc}$ & $2,1 \mathrm{~B}$ \\
$\mathrm{~S} / 2 \mathrm{~d} 46 \mathrm{~d} / 7 \mathrm{ET} 2.5 \% \mathrm{~Pa} 1(1) 4 / \mathrm{y}$ & $3,5 \mathrm{~b}$ & $0,7 \mathrm{c}$ & $2,1 \mathrm{~B}$ \\
$\mathrm{~S} / 2 \mathrm{~d} 46 \mathrm{~d} / 7 \mathrm{ET} 2.5 \% \mathrm{~Pa} 1(1)$ 8/y & $4,0 \mathrm{~b}$ & $1,3 \mathrm{~b}$ & $2,6 \mathrm{~B}$ \\
$\mathrm{~S} / 2 \mathrm{~d} 56 \mathrm{~d} / 7 \mathrm{ET} 2.5 \% \mathrm{~Pa} 1(1)$ 8/y & $3,8 \mathrm{~b}$ & $1,0 \mathrm{bc}$ & $2,4 \mathrm{~B}$ \\
$\mathrm{~S} / 2 \mathrm{~d} 6$ 6d/7 ET2.5\% Pa1(1) 10/y & $3,6 \mathrm{~b}$ & $0,4 \mathrm{c}$ & $2,0 \mathrm{~B}$ \\
\hline Mean & $4,0 \pm 1 \mathrm{~A}$ & $1,0 \pm 0,4 \mathrm{~B}$ & $2,5 \pm 0,7$ \\
\hline
\end{tabular}

In each column, the values assigned to the same letter are not significantly different (Student Newman-Keuls test at 5\%

Treatment without stimulation, with 100\% tapping intensity, recorded a moderate level of tapping panel dryness (5.8\%) and higher than those of other treatments which are low and statistically of the same order of magnitude. The highest tapping panel dryness rate in the high-frequency tapping system is probably due to an exacerbation of metabolic activation (over-sensed) leading to a large run-down of the production process and 
leading to an onset of physiological fatigue to the tapping panel dryness (Gohet, 1996; Soumahin, 2010). All the latex harvesting technologies combined, the level of tapping panel dryness is low (4\%). These results are consistent with previous studies of these clones PB 217 and PR 107 (Diarrassouba et al. 2012) and confirm that they belong to the slow metabolism clone class, which is recognized for its low sensitivity to tapping panel dryness (Eschbach et al. 1984; Serres et al. 1988; Jacob et al. 1995; Gohet et al. 1996). This is probably due to the fact that the high content of sucrose in the latex of this latex harvesting technology acts as a buffer reducing the extent of the antagonism between growth and rubber production as already noted by Gohet (1996). Our results corroborate those of Gohet (1996) who showed that rubber trees of this class can easily withstand an increase in the frequency of stimulation without risk of saturation of the function of production of latex which would lead to an increase of the rate of tapping panel dryness.

\section{Influence of Latex Harvesting Technologies on Physiological Profile of Clones with slow Metabolism PB 217 and PR 107}

Clone PB 217.The average solids content (Ex.S) of tree latex (downward tapping), all latex harvesting technologies, was very high $(50.3 \%)$. Overall, it seems to increase with the reduction in tapping intensity (Table 5). The sucrose content of all latex harvesting technologies reached 12.8 mmol. $1^{-1}$, which content is moderately high. Treatment without hormonal stimulation, with $100 \%$ tapping intensity, recorded the highest sucrose content $\left(15.4 \mathrm{mmol}^{-1}\right)$. The latter content is statistically equivalent to that of treatment 2 (d3-4/y) and slightly higher than that of the $3(\mathrm{~d} 4-4 / \mathrm{y}), 4(\mathrm{~d} 4-8 / \mathrm{y})$ and 6 (d6$10 / y)$ whose contents are statistically identical. Pattern 5 (d5-8/y), with $40 \%$ tapping intensity, recorded the most statistically low sucrose content (9.9 mmol. $\left.1^{-1}\right)$. The values of inorganic phosphorus (Pi) expressed are statistically of the same order of magnitude, regardless of the technology for harvesting the latex (Table 5). The average of these inorganic phosphorus $\left(22.1 \mathrm{mmol}^{-}\right.$ $\left.{ }^{1}\right)$ contents is high. The content of the thiol groups ( $\left.\mathrm{R}-\mathrm{SH}\right)$, with all the latex harvesting technologies, is moderate $\left(0.66 \mathrm{mmol}^{-1} \mathrm{l}^{-1}\right)$. Only the pattern without hormonal stimulation, with $100 \%$ tapping intensity, recorded a physiologically high thiol groups content $\left(0.81 \mathrm{mmol}^{-1}\right)$ while the other motifs expressed moderate and statistically equivalent contents.

Clone PR 107.The solids content, all technologies combined, reached a very high level $(50.1 \%$, Table 5). Overall, it seems to increase with the reduction in tapping frequency. This increase in solids content did not statistically differentiate latex harvesting technologies applied to trees. The sucrose content of all latex harvesting technologies was $11.0 \mathrm{mmol} . \mathrm{l}^{-1}$. This content is moderately high. Treatment without hormonal stimulation, with $100 \%$ tapping intensity, expressed the highest sucrose content $\left(13.8 \mathrm{mmol}^{-1}\right)$. 
The latter content is slightly higher than those of the $3(\mathrm{~d} 4-4 / \mathrm{y}), 4(\mathrm{~d} 4-8 / \mathrm{y})$ and 6 (d6-10/y) units, whose contents are statistically identical. Treatments 2 (d3$4 / y)$ and 5 (d5-8/y) showed the most statistically low levels of sucrose. Regardless of the latex harvesting technology, the inorganic phosphorus

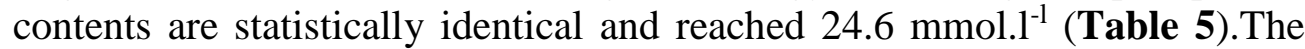
content of the thiol groups, with all the latex harvesting technologies, is good $\left(0.71 \mathrm{mmol}^{-1} \mathrm{I}^{-1}\right.$. The pattern without hormonal stimulation, with $100 \%$ tapping intensity, recorded the most statistically high thiol groups content $(0.78$ mmol. $\left.1^{-1}\right)$, which content is different from those of the other motifs which are statistically equivalent between them.

Table 5: Annual mean values of the physiological parameters of clones PB 217 and PR 107, tapping for nine years in south-west Côte d'Ivoire

\begin{tabular}{|c|c|c|c|c|c|c|c|c|}
\hline \multirow{3}{*}{ Treatements } & \multirow{2}{*}{\multicolumn{4}{|c|}{ PB 217}} & \multirow{2}{*}{\multicolumn{4}{|c|}{ PR 107}} \\
\hline & & & & & & & & \\
\hline & $\begin{array}{l}\text { ExS } \\
(\%)\end{array}$ & $\begin{array}{l}\text { Sac. } \\
(\mathrm{mmol} / \mathrm{l})\end{array}$ & $\begin{array}{l}\text { Pi. } \\
(\mathrm{mmol} / \mathrm{l})\end{array}$ & $\begin{array}{l}\mathrm{R}-\mathrm{SH} . \\
(\mathrm{mmol} / \mathrm{l})\end{array}$ & $\begin{array}{l}\text { ExS } \\
(\%)\end{array}$ & $\begin{array}{l}\text { Sac. } \\
(\mathrm{mmol} / \mathrm{l})\end{array}$ & $\begin{array}{l}\text { Pi. } \\
(\mathrm{mmol} / \mathrm{l})\end{array}$ & $\begin{array}{l}\text { R-SH. } \\
(\mathrm{mmol} / \mathrm{l})\end{array}$ \\
\hline d2-nil stim & $45,2 \mathrm{c}$ & $15,4 \mathrm{a}$ & $21,6 \mathrm{a}$ & $0,81 \mathrm{a}$ & $49 \mathrm{a}$ & $13,8 \mathrm{a}$ & $27,1 \mathrm{a}$ & $0,78 \mathrm{a}$ \\
\hline $\mathrm{d} 3-4 / \mathrm{y}$ & $48,2 \mathrm{bc}$ & $15,1 \mathrm{a}$ & $24,4 \mathrm{a}$ & $0,66 \mathrm{~b}$ & $48,3 \mathrm{a}$ & $8,8 \mathrm{~b}$ & $26,0 \mathrm{a}$ & $0,73 \mathrm{~b}$ \\
\hline $\mathrm{d} 4-4 / \mathrm{y}$ & $51,3 \mathrm{ab}$ & $12,0 \mathrm{ab}$ & $21,2 \mathrm{a}$ & $0,62 \mathrm{~b}$ & $50,4 \mathrm{a}$ & $11,2 \mathrm{ab}$ & $25,0 \mathrm{a}$ & $0,7 \mathrm{~b}$ \\
\hline $\mathrm{d} 4-8 / \mathrm{y}$ & $51,4 \mathrm{ab}$ & $13,1 \mathrm{ab}$ & $22,2 \mathrm{a}$ & $0,62 \mathrm{~b}$ & 50,6 a & $11,5 \mathrm{ab}$ & 23,9 & $0,69 \mathrm{~b}$ \\
\hline d5-8/y & $52,2 \mathrm{a}$ & $9,9 \mathrm{~b}$ & $22,0 \mathrm{a}$ & $0,62 \mathrm{~b}$ & $51,5 \mathrm{a}$ & $10,4 \mathrm{ab}$ & $23,0 \mathrm{a}$ & $0,68 \mathrm{~b}$ \\
\hline d6-10/y & $53,7 \mathrm{a}$ & $11,3 \mathrm{ab}$ & $21,1 \mathrm{a}$ & $0,60 \mathrm{~b}$ & $50,6 \mathrm{a}$ & $8,6 \mathrm{~b}$ & $22,6 \mathrm{a}$ & $0,67 \mathrm{~b}$ \\
\hline Mean & $50,3 \pm 3$ & $12,8 \pm 2$ & $22,1 \pm 1$ & $0,66 \pm 0,1$ & $\begin{array}{l}50,1 \pm \\
1\end{array}$ & $11 \pm 2$ & $24,6 \pm 1$ & $0,71 \pm 0$ \\
\hline
\end{tabular}

In each column, the values assigned to the same letter are not significantly different (Student Newman-Keuls test at 5\%

\section{Synthesis of Physiological Profile and Physiological Index of Clones slow or slow Metabolism PB 217 and PR 107}

On the physiological level, two groups of physiological parameters are noted; solids content and inorganic phosphorus which did not significantly differentiate latex harvesting technologies and other physiological parameters, especially sucrose and thiol groups, whose levels varied significantly according to the treatment (Table 6). Overall, the solids content ratio $(50.2 \%)$ and the sucrose content $\left(12.4 \mathrm{mmol}^{-1}\right)$ were very high, while the inorganic phosphorus content $\left(23.4 \mathrm{mmol}^{-1}\right)$ and thiol groups $\left(0.69 \mathrm{mmol} . \mathrm{l}^{-1}\right)$ are respectively high and moderate.In addition, the latex micro diagnosis made it possible to distinguish two groups of treatments; 1 (d2-nil stim), 2 (d3-4/y), 3 $(\mathrm{d} 4-4 / \mathrm{y})$ and $4(\mathrm{~d} 4-8 / \mathrm{y})$ whose trees have a well-balanced physiological state and other treatments, including $5(\mathrm{~d} 5-8 / \mathrm{y})$ and 6 (d6-10/y), whose tree physiological states are well balanced (Table 6). Overall, the latex diagnosis shows that the physiological state of the trees relative to the different latex harvesting technologies applied to trees is very well balanced. 
The physiological index decreased with the reduction in tapping frequency (Table 6). Treatment without hormonal stimulation, with $100 \%$ tapping intensity, expressed the highest physiological index (287.7). This physiological index is followed by those of treatments $2(\mathrm{~d} 3-4 / \mathrm{y}), 3(\mathrm{~d} 4-4 / \mathrm{y})$ and $4(\mathrm{~d} 4-8 / \mathrm{y})$ which are statistically similar to one another. The lowest physiological indices are displayed by treatments 5 (d5-8/y) and 6 (d6-10/y). These last physiological index are also statistically identical. The change from 4 to 8 annual stimulations for the same tapping frequency $(\mathrm{d} 4)$ did not have a significant influence on the physiological index (d4-4/y: 210.5; d4-8/y: 197.2). On the other hand, reduction of the frequency of tapping of all four (d4) every five (d5) days for the same hormonal stimulation frequency $(8 / y)$ resulted in a decrease in physiological index (d4-8 / y: 197.2 and d5-8 / y: 159.8). This was not the case for the $\mathrm{d} 3-4 / \mathrm{y}$ (218.8) and $\mathrm{d} 4-4 / \mathrm{y}$ (210.5) treatments where the physiological index are statistically identical. In fine, the physiological index distinguishes three groups of treatments; the first group is the only technology for harvesting unstimulated latex. The second group is latex harvesting technology, tapping every three (3) days and tapping every four (4) days. The third group consists of the last two latex harvesting technologies.

Table 6: Synthesis of physiological profiles and average values of physiological index of clones PB 217 and PR 107 in tapping downward during nine years of experimentation with respect to the six latex harvesting systems

\begin{tabular}{|c|c|c|c|c|c|c|}
\hline \multirow{2}{*}{ Traitements } & \multicolumn{4}{|c|}{ PhysiologicalParameters } & \multirow{2}{*}{$\begin{array}{l}\text { physiological } \\
\text { profile }\end{array}$} & \multirow{2}{*}{$\begin{array}{l}\text { Physiological } \\
\text { index }\end{array}$} \\
\hline & ExS & Sac. $(\mathrm{mmol} / \mathrm{l})$ & Pi. (mmol/l) & R-SH. (mmol/l) & & \\
\hline $\mathrm{d} 2$ nil & $47,1 \mathrm{~A}$ & $14,8 \mathrm{~A}$ & $24,3 \mathrm{~A}$ & $0,80 \mathrm{~A}$ & Very balanced & $287,7 \mathrm{~A}$ \\
\hline d3-4/y & $48,3 \mathrm{~A}$ & $12,4 \mathrm{~B}$ & $25,2 \mathrm{~A}$ & $0,70 \mathrm{~B}$ & Very balanced & $218,8 \mathrm{~B}$ \\
\hline $\mathrm{d} 4-4 / y$ & 50,9 A & $13,4 \mathrm{~A}$ & $23,1 \mathrm{~A}$ & $0,68 \mathrm{~B}$ & Very balanced & $210,5 \mathrm{~B}$ \\
\hline $\mathrm{d} 4-8 / \mathrm{y}$ & $51,0 \mathrm{~A}$ & $12,8 \mathrm{~B}$ & $23,0 \mathrm{~A}$ & $0,67 \mathrm{~B}$ & Very balanced & 197,2 B \\
\hline $\mathrm{d} 5-8 / \mathrm{y}$ & $51,9 \mathrm{~A}$ & $10,6 \mathrm{C}$ & $22,5 \mathrm{~A}$ & $0,67 \mathrm{~B}$ & Balanced & $159,8 \mathrm{C}$ \\
\hline d6-10/y & $52,2 \mathrm{~A}$ & $10,4 \mathrm{C}$ & $21,8 \mathrm{~A}$ & $0,65 \mathrm{~B}$ & Balanced & $147,4 \mathrm{C}$ \\
\hline Mean & $50,2 \pm 2$ & 12,4 & 23,4 & $0,69 \pm 0,1$ & Very balanced & 200,2 \\
\hline
\end{tabular}

Choosing better latex harvesting systems for slow metabolism clones

The aim of this study on slow metabolism clones (PB 217 and PR 107) is to determine the best latex harvesting system (s) applied to them. This is based on the physiological and sanitary parameters, in particular sensitivity to the tapping panel dryness.

With respect to agronomic parameters, especially rubber production, all latex harvesting technologies are equivalent. However, with respect to bark consumption, latex harvesting technology; $(15.6<$ consumption $(\mathrm{cm})<20.3)$ than all other latex harvesting technologies, including weekly tapping $(9.4<$ consumption $(\mathrm{cm})<10.4)$ according to the work of Obouayeba et al. (2009) which, therefore, does not recommend it for implementation.

Compared to sensitivity to the tapping panel dryness, trees of latex harvesting technology without hormonal stimulation are distinguished by their 
sensitivity to the higher tapping panel dryness. Thus, it appears that latex harvesting technology without hormonal stimulation of production can not be among the best.

As regards the physiological parameters, it appears from the synthesis of the physiological profiles that globally two main groups of treatments are noted; the first group is formed by the technologies for harvesting latex $\mathrm{d} 2$-nil stim, d3-4/y, d4-4/y and d4-8/y, with a well-balanced physiological profile. The second group consists of the two (2) latest latex harvesting technologies whose physiological profile is well balanced. The physiological index, produced from contents of sucrose, inorganic phosphorus and thiol groups, distinguishes three groups of treatments; the first group is formed by the technology of harvesting unstimulated latex. The second group is latex harvesting technology, tapping every three (3) days and tapping every four (4) days. The third group consists of the last two latex harvesting technologies.

Our results show that latex harvesting technology without hormonal stimulation of rubber production is the most interesting relative to its rubber productivity and especially to its physiological profile, expressed by the tapped trees, which is significantly the best of all. However, this latex harvesting technology presents a prohibitive parameter to its promotion. Indeed, the sensitivity to the tapping panel dryness expressed by the trees of this high treatment is a handicap to the management of the plantation. In addition, the bark consumption of this latex harvesting technology, from onethird to almost double that of other latex harvesting technologies, poses a significant funding problem for the management of rubber production on the long term. This parameter constitutes, in fine, an important constraint to the sustainable management of rubber production in a plantation. The bark consumption, which is the capital of the rubber tree, negatively influences the management time of a plantation's rubber production by reducing it by onethird to one-half in relation to other latex harvesting technologies.

The results of the physiological index and that of the consumption of bark determine us to retain for better technologies of harvesting of the latex to apply to the clones with low active metabolism (slow), the tappings every three (3) and every four (4 days.

\section{Conclusion}

In the first nine years after the opening of the tapping panel of the slow metabolism clones (PB 217 and PR 107), the results indicate that these clones have good rubber productivity $\left(2026 \mathrm{~kg} \cdot \mathrm{ha}^{-1} \cdot \mathrm{y}^{-1}\right)$, with good radial vegetative growth (2.6 cm. $\left.\mathrm{y}^{-1}\right)$, a well-balanced physiological profile and a low sensitivity to the dry notch $(2.5 \%)$. The analysis of the influence of latex harvesting technologies on the agronomic, physiological and sanitary parameters makes it possible to conclude that they are almost all adapted to 
clones with a slow or slow metabolism. However, the physiological index and the bark consumption discriminate them sufficiently enough to retain only the latex harvesting technologies "S/2 d3 6d/7 Pa1(1) ET2.5\% 4/y, S/2 d4 6d/7 $\mathrm{Pa} 1$ (1) ET2.5\% 4/y and S/2 d4 6d/7 Pa1(1) ET2.5\% 8/y" for the best. The latex micro-diagnosis, through the physiological index, played a predominant role in the choice of latex harvesting technologies suitable for slow metabolism clones: PB 217 and PR 107. It thus contributes to the modern and efficient management of plantations rubber growing.

\section{References:}

1. Abraham, P.D., Wycherly, P.R., \& Pakianathan, S.W. (1968). Stimulation of latex flow in Hevea brasiliensis by 4-amino-3,5,6trichloropicolinic and 2-chloroethane phosphonic acid. J. Rubb. Res. Inst. Malaya, 20 (29), 1-305.

2. Ashwell, G. (1957). Colorimetric analysis of sugar. Methods Enzymol., 3, 73-105.

3. Atsin, G.J.O., Soumahin, E.F., Kouakou T.H., Elabo, A.E.A., Okoma, K.M., \& Obouayeba, S. (2016). Agronomic Potential of Some Rubber Tree Clones (Hevea brasiliensis) of the Fast Metabolic Activity Class in the Absence of Hormonal Stimulation in Southwestern of Côte d'Ivoire. Am. J. Exp. Agri., 13 (4), 1-13

4. Boyne, A.F., \& Ellman, G.I. (1972). A methodology for analysis of tissue sulphydryl components. An. Biochem., 46, 639-653.

5. Chapuset, T. (2001). Description des clones étudiés à grande échelle ; Rapport CNRA-HEVEA n01/01 - A- Mai 2001.

6. Chrestin, H. (1985). La stimulation à l'Ethrel de l'hévéa; jusqu'où ne pas aller trop loin. Caoutch. Plast., 647/648, 75-78.

7. Dian, K. (1997). Tapping Panel Dryness Research : List of questions. Int. Rubb. Res. Dev. Board (IRRDB). 1.

8. Diarrassouba , M., Soumahin E.F., Coulybaly, L.F., N'guessan, A.E.B., Dick, K.E., Kouame, C., Obouayeba, S., \& Ake, S. (2012). Latex harvesting technologies adapted to clones PB 217 and PR 107 of Hevea brasiliensisMuell. Arg. of the slow metabolism class and to the socio-economic context of Côte d'Ivoire. Int. J. Biosci., 2, 125-138.

9. Eschbach, J.M., Roussel, D., Van De Sype, H., Jacob, J.L., \& D’Auzac, J., (1984). Relationships between yield and clonal physiological characteristics of latex from Hevea brasiliensis. Physiol. Vég., 22: 295-304.

10. Gohet, E. (1996). La production de latex par Hevea brasiliensis. Relation avec la croissance. Influences de différents facteurs: Origine clonale, stimulation hormonale, réserves hydrocarbonées. Thèse de 
doctorat d'université, Université Montpellier II, Sciences et Techniques du Languedoc, Montpellier(France).

11. Gohet, E., Prévôt, J.C., Eschbach, J.M., Clément-Vidal, A., \& Jacob, J.L. (1996). Clone, croissance et stimulation, facteurs de la production de latex. Plant. Rech. Dev., 3, 30-38.

12. Jacob, J.L., Eschbach. J.M., Prévôt, J.C., Roussel, D., Lacrotte, R., Chrestin, H., \& D'Auzac, J. (1985). Physiological basis for latex diagnosis of the functioning of the laticiferous system in rubber trees. In: Rubb. Res. Inst. Malaysia, ed. Proc. Int. Rubb. Conf., Kuala Lumpur (Malaysie).

13. Jacob, J.L., Lacrotte, R., Serres, E., \& Roussel, D. (1987). Les paramètres physiologiques du latex d'Hevea brasiliensis, le diagnostic latex, ses bases et sa mise au point. Ekoma, février 1987.

14. Jacob, J.L., Serres, E., Prévôt, J.C., Lacrotte, R., Clément-Vidal, A., Eschbach, J.M., \& D’Auzac, J. (1988). Mise au point du diagnostic latex. Agritrop., 12, 97-118.

15. Jacob, J.L., Prévôt, J.C., Eschbach, J.M., Lacrotte, R., Serres, E., \& Clément-Vidal, A. (1990). Latex flow, cellular regeneration and yield of Hevea brasiliensis. Influence of hormonal stimulation. In: International congress of plant physiology, New Dehli, Inde 15-20 fév. 1988. Vol. 1, Sinha S.K., Sane P.V, Bhargawa S.C \& Agrawal P.K. éd., New Dehli, Ind., Society for Plant Physiology and Biochemistry, 426-433.

16. Jacob, J.L., D’Auzac, J., Prévôt, J.C., \& Sérier, J.B. (1995). Une usine à caoutchouc naturel: l'hévéa. La recherche, 276, 538-545.

17. Koffi, K.E., Elabo, A.A.E., \& Gnagne, Y.M. (2004). Qualité sélective des paramètres physiologiques dans la sélection précoce de l'hévéa (Hevea brasiliensis Muell Arg.). Agronomie Africaine, 16, 1-10.

18. Lacote, R., Gabla, O., Obouayeba, S., Eschbach, J.M., Rivano, F., Dian, K., \& Gohet, E. (2010). Long-term effect of ethylene stimulation on the yield on rubber trees is linked to latex cell biochemistry. Fie. Cro. Rese., 115: 94-98.

19. Obouayeba , S. (1993). Estimation de la quantité de pâte stimulante appliquée sur Hévéas en fonction de leur circonférence au sud-est de la Côte d'Ivoire. Agronomie Africaine, 5, 25-32.

20. Obouayeba, S. \& Boa, D. (1993). Fréquence et repos annuel de saignée d'Hevea brasiliensis, clone PB 235, dans le sud-est de la Côte d'Ivoire. Cahiers Agricultures, 2, 387-393.

21. Obouayeba, S. (1995). Récolte de latex de l'hévéa en milieu non industriel. Document de formation des encadreurs du milieu hévéicole non industriel, Projet Hévéa 5 bis. 
22. Obouayeba, S., Boa, D., \& Kéli, Z.J. (1996). Adéquation entre quantité de Pâte stimulante et production de caoutchouc d'Hevea brasiliensis dans le Sud-est de la Côte d'Ivoire. Tropicultura. 14, 54-58.

23. Obouayeba, S., Boa, D., \& Aké, S. (2000). Critical age bark growth and latex vessel formation as attributes for determination of tapping norms. Indian J. Nat. Rubb. Res., 13, 38-45.

24. Obouayeba, S., Boa, D., Aké, S., \& Lacrotte, R. (2002). Influence of age and girth at opening on growth and productivity of Hevea. Ind. J. Nat. Rub. Res., 15, 66-71.

25. Obouayeba, S. (2005). Contribution à la détermination de la maturité physiologique de l'écorce pour la mise en saignée d'Hevea brasiliensis Müell. Arg. (Euphorbiaceae) : normes d'ouverture. Thèse de doctorat d'université, Université de Cocody, Physiologie Végétale, Abidjan (Côte d'Ivoire).

26. Obouayeba, S., Dian, K., Boko, A.M.C., Gnagne, Y.M., \& Aké, S. (2005). Effect of planting density on growth and yield productivity of Hevea brasiliensis Muell. Arg. clone PB 235. Journal of Rubber Research, 8 (4), 257-270.

27. Obouayeba, S., (2009). Saignée de faible intensité appliquée au clone d'Hevea brasiliensis $\mathrm{PB} 217$ pour palier à une pénurie et/ou une cherté de la main d'œuvre saigneur. Fiche technique.

28. Obouayeba, S., Soumahin, E.F., Dobo, M., Lacote, R., Gabla, O., \& Doumbia, A. (2009). Agronomic performance of clone IRCA 111 of Hevea brasiliensis under different frequencies of tapping and stimulation in South-West Côte d'Ivoire. J. Rub. Res., 12, 93-102.

29. Serres, E., Clément-Vidal, A., Prévôt, J.C., Jacob, J.L., Commère, J., Lacrotte, R., \& Eschbach, J.M. (1988). Typologie clonale des tissus laticifères chez Hevea brasiliensis. In: J.L. Jacob and J.C. Prévôt (Editors), Exploitation - Physiologie et Amélioration de 1'Hevea. IRCA-CIRAD, Montpellier, pp 231-246.

30. Serres, E., Lacrotte, R., Prévôt, J.C., Clément-Vidal, A., Commère, J., \& Jacob, J.L. (1994). Metabolic aspects of latex regeneration in situ for three Hevea clones. Rubb. Ind. J., 7, 79-84.

31. Soumahin, E.F. (2010). Optimisation des systèmes d'exploitation en hévéaculture par la réduction des intensités de saignées. Thèse de doctorat d'université, Université de Cocody, Abidjan, Côte d'Ivoire.

32. Taussky, H.H., \& Shorr, E. (1953). A micro colorimetric method for the determination of inorganic phosphorus. J. Biol. Chem., 20, 675685.

33. Thomas, V., Premakumari, D., Reghu, C.P., Panikkar, A.O.N., \& Saraswathy, A.C.K. (1995). Anatomical andhistochimical aspects of bark regeneration in Hevea brasiliensis. Ann. Bot. Comp., 75: 421-426. 
34. Traoré, M.S., Dick, E.A., Elabo, A.E.A., Soumahin, E.F., Assi EGM, Atsin O.G.J., Allé Y.J., N'Guéssan A.E.B., Kouamé C., Obouayeba, S. (2014). Effets de différentes fréquences annuelles de stimulation éthylénique sur les paramètres agrophysiologiques et de sensibilité à l'encoche sèche d'Hevea brasiliensis au sud-est de la Côte d'Ivoire : cas des clones PB 235 et PB 260 de la classe d'activité métabolique rapide. Int. J. Biol. Chem. Sci. 8, 956-974.

35. Wycherley, P.R., (1975). Hevea long flow, adverse partition and storm lose, Plant. Kua. Lump., 51, 6-13. 